the excavations of Mr. Theodore M. Davies with some remarkable finds. No striking results were obtained until November 5 last, when Mr. Carter discovered the tomb of King Tutankhamen-a discovery unique in the annals of archæology. The interest of the objects taken from the tomb, remarkable both in their number and character, grew from day to day, and culminated on February $\mathrm{I}$, when the opening of the inner chamber revealed the shrines in which it is expected that the body of the king will be found. Work was then closed for the season.

It adds a note of tragedy to Lord Carnarvon's death that he will not be present when the opening of the innermost shrine crowns his labours, but his name will always be honoured as one who added a vast store to our knowledge of the civilisation of Ancient Egypt.

\section{Dr. C. I. Forsyth Major, F.R.S.}

Dr. Charles Immanuel Forsyth Major, who died at Munich on March 25, aged seventy-nine, was born in Glasgow, of Scottish parents, but removed when an infant to Constantinople, and lived for most of his life abroad. He was educated in Switzerland, Germany, and Italy. Graduated Doctor of Medicine in Basle in $\mathbf{I} 868$, and began his career as a medical practitioner in Florence.

Dr. Major was, however, always interested in natural history, and his association with Rütimeyer in Basle led him to become an enthusiastic student of fossil mammals. While occupied with his professional duties in Florence, he took every opportunity of collecting and examining the mammalian remains found in the superficial deposits in the valley of the Arno, and from I872 onwards he published in Italy a series of small papers on these remains, describing and discussing them in a more exhaustive manner than had previously been attempted. He summarised his results in the Quarterly Journal of the Geological Society of London in $\mathrm{x} 884$, pointing out that the later Pliocene mammals were all distinguishable from those of the early Pleistocene when fossils were studied in detail. At the same time he published valuable memoirs on the dentition of rodents from the Bohnerz of Switzerland and South Germany (Palcontographica, xxii., r873), and on the dentition of the early true horses (Abhandl. Schweiz. Paläont. Ges., I877-80).

About I886 Dr. Major abandoned his medical practice, and began to devote himself entirely to scientific research. With the help and encouragement of his Swiss friend, M. W. Barbey, he made a thorough exploration of the Pliocene accumulation of mammalian bones in the island of Samos, and brought back a great collection, of which part was presented by M. Barbey to the Collège Gaillard at Lausanne, and the other part was purchased by the British Museum. In I889 Dr. Major made another important collection of mammalian remains from a Pliocene torrent-deposit at Olivola in the Carrara mountains in Italy, and this was also purchased by the British Museum. Dr. Major followed his collections to the British Museum, and was temporarily employed there in cataloguing the fossil mammals until r909. While thus occupied he published a valuable series of papers in London. He also arranged to prepare a Catalogue of Fossil Rodentia for the
British Museum, and a large monograph of the Samos Mammalia, which unfortunately were never produced.

In 1893 Dr. Major contributed his important memoir on the skull of a giant lemur, Megaladapis, from a cavern in Madagascar, to the Philosophical Transactions of the Royal Society, and the novelty of this discovery led him to plan an exploration of the caverns and marshes of Madagascar. With the aid of a government grant from the Royal Society, he visited Madagascar in I894-95, and brought back an important collection of fossil mammals and birds, which is also now in the British Museum. On these fossils he wrote several descriptive papers.

In his later years, however, Dr. Major found increasing difficulty and diffidence in preparing his results for publication, although his researches were pursued with accustomed diligence. Much of his valuable work on rodents and on the relationship between the fossil Samotherium, which he discovered in Samos, and the existing okapi of the Congo Forest, is thus unfortunately lost to science. Dr. Major was elected a fellow of the Royal Society in rgo8, and about the same time was awarded a small Civil List pension. $\mathrm{He}$ then returned to the Mediterranean region which had interested him for so many years, and spent most of the remainder of his life in Corsica. He still continued to collect and study mammalian remains, chiefly from the caverns and rock-fissures of Corsica, but he now ceased to do more than make manuscript notes.

A. S. W.

\section{Mr. E. W. VREDENBURG.}

GEOLOsy has lost a cultured worker by the death of Frnest Watson Vredenburg, who passed away on March I2, at the age of fifty-three. His death was probably hastened by the constant and now painfully verified foreboding that he might never be able to finish the great task which he had undertaken of revising the Tertiary palæontology of the Indian region. We have had occasion at times to notice some of the numerous instalments which he has published during the past few years in the Records of the Geological Survey of India; they and other papers now in the press were intended to prepare the way for a comprehensive monograph which he hoped would justify his reason for differing from his colleagues on some questions of stratigraphical correlation; but the burden was too great for that hyper-sensitive, artistic, and retiring nature which tended to keep him apart from his colleagues, who nevertheless appreciated his deep learning, unrelenting industry, and tenacious adherence to independent views.

Mr. Vredenburg, who was half French in race and wholly so in upbringing, graduated at Paris in Science and Letters before entering the Royal College of Science and School of Mines, where he took a double associateship, in geology and mining, before joining the Geological Survey of India in I895. He spent the first part of his official work on the relatively uninteresting unfossiliferous rocks of Central India, and did not get an opportunity of discovering his main bent till his transfer to Baluchistan, the geological features of which he revised and summarised in rgro. There and in the adjoining regions of Sind he became deeply interested in the stratigraphy and palæontology of the 
Lower Tertiary system, extending his work afterwards to the younger beds in the Burma oil-fields.

South Kensington students will remember him as a brilliant pianist who would have had a distinguished position in the musical world if he had not concentrated on the palæontology of India. During his early days in India be showed a tendency to become engrossed in archæological interests until palæontology claimed him first as a devotee and finally as a victim.

\section{Count Fernand de Montessus de Ballore.}

THE small band of seismologists has suffered a serious loss through the death of M. de Montessus de Ballore. Born in $185 \mathrm{I}$, he was trained at the École Polytechnique, where he was a fellow-student of Marshal Foch. In I88I he was sent as chief of a military mission to San Salvador. There he became interested in the frequent earthquakes of the Central American republics, and he continued his seismological studies on his return to Paris as Directeur des Études at the École Polytechnique. In 1907 he was appointed director of the earthquake-service in Chile, a service which, through his efforts, became one of the first rank.

De Montessus will be chiefly remembered and valued for his studies on the distribution of earthquakes. His great work on "Géographie Séismologique," which occupied his leisure for twenty-four years, was published in rgo6. Few men could be so well qualified as he for an undertaking so vast, for he had a good knowledge of six foreign languages. Having collected records of nearly 160,000 earthquakes, he showed that seismic regions follow the principal lines of relief, that, in a group of unstable regions, the most unstable are those of the greatest relief, and that more than 90 per cent. of the earthquakes occurred along two narrow zones occupying great circles of the earth, which he called the Mediterranean circle and the circum-Pacific circle. In 1907 his second work, "La Science Séismologique," appeared and at once took its place as an authoritative treatise.

Besides these two volumes and a small popular book published in rgr I, de Montessus was the author of many memoirs. One of the latest was a bibliography of seismology containing the titles of more than 9000 books and papers. In the preparation of these works, he had collected a library, perhaps the most extensive of the kind in existence. This was bought a few years ago by the late President J. C. Branner, and was presented by him to the University of California. C. D.

\section{Prof. M. Abraham.}

THE issue of the Physikalische Zeitschrift for February I contains an obituary notice of Prof. Max Abraham by Profs. M. Born and M. v. Laue. He was born at Danzig in 1875 and studied under Planck at Berlin. After graduating he became Planck's assistant, and in I900 privatdozent at Göttingen. For a short time in 1905 he acted as professor at the University of Illinois, and, after his return to Göttingen, was in I909 appointed professor of theoretical physics at Milan. The War ended this, and he held temporary posts till last year, when he was appointed professor of theoretical mechanics at Aix-la-Chapelle. Illness prevented him commencing duties there, and he died of tumour on the brain on November I6, 1922. He was well known in this country for his book "Theorie der Elektrizität," for his articles on vectors and on electromagnetic waves in the "Mathematische Encyklopädie," and for his papers on the dynamics of electrons, all giving evidence of a clear and logical mind.

WE regret to learn from Australia of the death, at the end of January, of Dr. J. L. Glasson, at the age of thirty-four years. Dr. Glasson was a student of the University of Adelaide, where he worked under Sir William Bragg, and from that University he received his doctor's degree. He succeeded in winning a travelling research scholarship of the Exhibition of $185 \mathrm{I}$, and with it came to this country. He entered Gonville and Caius College, Cambridge, in 1909 as an advanced student, and, going to the Cavendish Laboratory, did valuable research work under Sir J. J. Thomson. In I 912 he was appointed lecturer in physics in the University of Tasmania, Hobart, and while there he did valuable work for the Electrolytic Zinc Co. and for the Tasmanian Carbide Co. This post he resigned in 1919 , returning to Cambridge for research for a couple of years, after which he accepted an appointment as lecturer in physics in the University of Melbourne, which he held at the time of his death.

THE sudden death from angina pectoris on March I $_{5}$ of Mr. G. E. Bullen, Curator of the Herts County Museum at St. Albans, is announced. Among the smaller museums in the country there can be few which have been raised to such a pitch of excellence, and this has been due entirely to the whole-hearted devotion and enthusiasm of Mr. Bullen during the past twenty years. A considerable extension and rearrangement of the collections has recently been completed, and, especially on the archæological side, the museum is now a model of what a local museum should be, the clear demonstrative labelling of the exhibits being a special feature. Mr. Bullen's work had been for some time carried on in defiance of indifferent health, and his death at the early age of forty is a great loss.

THE Chemiker Zeitung of March I7 announces the death in the beginning of March of Prof. Robert Scheibe, formerly professor in the Academy of Mines, Berlin, and later active in South-west Africa and Bolivia. In the issue of March I $_{5}$ the death on March ro of Prof. Ernst Salkowski, since I880 director of the chemical side of the Berlin Pathological Institute, is announced. Prof. Salkowski was born on October II, I844, in Königsberg, and at first worked with Virchow. His researches covered a wide field in physiological chemistry.

WE regret to announce the following deaths :

Dr. H. H. Stoek, professcr of mining engineering in the University of Illinois since I909, on March I, aged fifty-seven.

Dr. John Venn, F.R.S., president of Gonville and Caius College, Cambridge, and for many years lecturer in logic and moral philosophy in the University, on April 4, aged eighty-cight.

Mr. S. H. Wells, director-general of the Egyptian Department of Technical, Industrial, and Commercial Education since 1907 , on March 28, aged fifty-seven. 